\title{
EDUCAÇÃO AMBIENTAL E TECNOLOGIAS: EXPERIÊNCIAS RELACIONADAS À EXTENSÃO UNIVERSITÁRIA
}

\author{
Maiane Lima Teles, Universidade Federal de Campina Grande- CFP \\ maianelimat@gmail.com \\ Astânia Ferreira Pessoa, Universidade Federal de Campina Grande- CFP \\ pedag.astaniapessoa@gmail.com
}

Yam de Sousa Santos, Laboratório do Grupo de Estudos e Pesquisas em Representações

Sociais na/para Formação de Professores - LAGERES

yamssantos@gmail.com

PALAVRAS-CHAVE: Tecnologias de Informação e Comunicação; Ensino Inovador; Interdisciplinaridade; Formação continuada;

KEYWORDS: Information and Communication Technologies; Innovative Teaching; Interdisciplinarity; Continuing Education;

PALABRAS CLAVE: Tecnologías de Información y Comunicación; Enseñanza Innovadora; Interdisciplinariedad; Formación continua;

\section{INTRODUÇÃO}

Observamos, na atualidade, a necessidade de mudança no comportamento do Ser Humano com as questões ambientais. Vivemos em uma sociedade de cultura ariscada, explorando e consumindo recursos naturais de forma desenfreada, colocando em risco a existência das comunidades biológicas (HENRIQUES, et al., 2007). A educação ambiental (EA) imerge em tal contexto com o intuito de formar o sujeito ecológico (CARVALHO, 2012) - indivíduos com percepção de meio, conscientes e preocupados com a preservação e manutenção do meio ambiente, permitindo e proporcionando uma formação critica reflexiva com capacidade de compreender e interferir de forma positiva no meio no qual está inserido (JACOBI, 2003).

Nessa perspectiva, a utilização de uma metodologia pensando nas Tecnologias de Informação e Comunicação (TICs) facilita o processo de ensino-aprendizagem e 
permite a disseminação dos conteúdos, universalizando o conhecimento através de blogs, sites, entre outros (DIAS, et al., 2016). A inovação tecnológica a favor da natureza tem como principal objetivo, amenizar os impactos ambientas negativos gerados pelo ser humano (CORRÊA, et all., 2010).

Pensando na EA, relacionando-a as tecnologias inovadoras, o projeto de extensão "Pedagogia Ambiental: a Tecnologia a Favor da Natureza" — materializando os objetivos do LIFE (Laboratório Interdisciplinar de Formação de Educadores) em promover ações extensionistas, com cursos de formação aos professores, da experimentação da docência usando a dialética como método de ensino concomitantemente com a pesquisa — se propõe a debater as questões de Meio Ambiente e Educação Ambiental nas escolas públicas municipais de Cajazeiras - PB.

Este trabalho se propõe a destacar as principais ações realizadas até o momento com o Projeto de Extensão "Pedagogia Ambiental: A Tecnologia a Favor da Natureza".

\section{METODOLOGIA}

Foram entregues convites para os coordenadores de duas escolas públicas de Cajazeiras, na Paraíba para desenvolvimento de atividades planejadas com as escolas. As reuniões acontecem no LIFE e são executadas pelos próprios extensionistas. Através de oficinas e debates nas escolas é promovida a Educação Ambiental (EA) por meio da dialética, além de mapear inovações tecnológicas a favor do meio ambiente, com estudantes da Educação Básica.

Na primeira reunião com as escolas foram realizadas duas ações. A primeira foi de aplicar um survey, em que os professores se posicionaram sobre suas expectativas. E, na sequência as atividades programadas para oferecer o projeto de extensão junto às escolas foram apresentadas.

A avaliação diagnóstica conteve três questões para verificar as expectativas dos professores sobre a relação de formação entre a escola e a universidade - CFP/UFCG. A primeira questão chama para o interesse do professor. Portanto se perguntava sobre qual era a expectativa em relação ao Projeto de Formação Continuada de Professores PROINTICS, tendo respostas diretivas para aferir o que o professor esperava do projeto. 
Entre os índices de medida de expectativa cinco itens foram disponibilizados. São eles: a) Muito Otimista; b) Otimista; c) Indiferente; c) Muito Pessimista e d) Pessimista. Nesse quesito, também foi solicitado que houve o registro de comentário sobre a expectativa.

A segunda questão era aberta e questionava sobre quais atividades o professor esperava desenvolver na formação de educadores do PROINTICS. Por fim, a terceira questão de exigência subjetiva era para o professor destacar algumas observações e ou comentários sobre qualquer aspecto que considerasse relevante para o andamento dos trabalhos.

Foram, ainda, realizados estudos de textos sobre interdisciplinaridade com estudantes bolsistas e voluntários.

\section{DESCRIÇÕES, RESULTADOS, INTERPRETAÇÕES (PARCIAIS E ESPERADOS)}

O Projeto de Extensão "Pedagogia Ambiental: a Tecnologia a favor da Natureza" vem desenvolvendo ações em sinergia com os outros projetos vinculados ao PROINTICS. No qual, articula ações no planejamento das atividades voltadas à formação continuada de docentes da rede municipal de ensino da cidade de Cajazeiras $\mathrm{PB}$, organizando oficinas pedagógicas em equipe, centradas no ensino de ciências para alunos do fundamental II, além de, Minicursos, Palestras e Debates que possibilitam a discussão do ensino de ciências, EA e inovações tecnológicas. As atividades são pensadas e desenvolvidas articulando o cronograma das escolas e dos professores ao cronograma da Universidade.

De acordo com as respostas contidas na avaliação diagnostica realizada no inicio das ações onde, $23 \%$ dos professores se mostraram muito otimistas com o programa, e $77 \%$ se mostraram otimistas na expectativa de desenvolver algo novo para os alunos através de uma inovação metodológica, de crescimento profissional e mudança no ensino, utilizando de atividades contextualizadas, interdisciplinares, que promovam o entusiasmo e aumentem a autoestima de todos os envolvidos, agindo como um facilitador no processo de ensino-aprendizagem. Para tanto, foram sugeridas diversas atividades pelos professores entrevistados, como oficinas, feira de ciências, estudo de campo, horta escolar, pomar escolar, atividades culturais e atividades coletivas. 
Compreender as expectativas dos professores da rede municipal de ensino em relação ao projeto, permite desenvolver ações de modo que supere tais expectativas. Dessa forma, o Projeto de extensão "Pedagogia Ambiental: A tecnologia favor da natureza" espera desenvolver as seguintes ações, ao longo de sua execução:

- Desenvolver junto aos professores modalidades didáticas diferenciadas para tratar conteúdos de ciências mediados pela inovação tecnológica;

- Mapeamento de resíduos sólidos para pensar a arborização;

- Mapear os tipos de árvores plantados na Avenida José Donato Braga;

- Alimentação de mídia nos grupos e redes sociais que serão criados para o compartilhamento das experiências;

- Elaboração de apresentação dos resultados em evento científico;

- Participar da elaboração do relatório final;

\section{CONSIDERAÇÕES FINAIS}

Tendo alcançado, ate então, os objetivos propostos, o projeto ganha visibilidade no CFP por meio das iniciativas e interesse dos alunos em participar. A ação direta dos estudantes em cada fase/ momento do projeto denta a vontade de intervir na sociedade para colaborar com a solução de problemas e/ ou dificuldades de ensino- aprendizagem por meio de estratégias que permitam desenvolver ações conjuntamente com os professores da rede publica. Os professores do projeto se mostram animados em replicar e construir os processos em outras escolas para favorecer a toda rede de ensino de Cajazeiras frente às questões ambientais. 


\section{REFERÊNCIAS}

ACOBI, P. et al. Educação ambiental, cidadania e sustentabilidade. Cadernos de pesquisa, v. 118, n. 3, p. 189-205, 2003.

CARVALHO, Isabel Cristina de Moura. Educação Ambiental: a formação do sujeito ecológico - 6ed. São Paulo: Cortez. 2012. 255p.

CORRÊA, C. R. et al. Inovação tecnológica e meio ambiente no Brasil. 2013.

DIAS, L. S. et all. Educação, Educação Ambiental, Percepção Ambiental e

Educomunicação. In: et all. (orgs.). EDUCAÇÃO AMBIENTAL:

conceitos, metodologias e práticas. Tupã: ANAP, 2016. p. 12-44.

HENRIQUES, R. et all. (orgs.). Educação Ambiental: aprendizes de sustentabilidade. Brasília: Secad/MEC, mar. 2007. 